\title{
Aristolochia indica: A Review
}

\author{
Mohit Marwaha *1, Dinesh Kumar ${ }^{1}$, Pooja Sharma ${ }^{1,2}$ \\ ${ }^{1}$ Sri Sai College of Pharmacy, Manawala, Amritsar-143115, Punjab, India \\ ${ }^{2}$ Department of Pharmaceutical Sciences and Drug Research, Punjabi University Patiala, Punjab, India
}

Address for Correspondence: Mohit Marwaha; MohitMarwaha1995@ yahoo.com

Received:
01.03.2019
Accepted:
25.03.2019
Keywords
Aristolochia
indica; Aqueous
extract of the
roots;
Aristolochic
acid; Anti-snake
venom; Essential
oil.

ABSTRACT: Aristolochia Indica has been widely used in the traditional medicine for the treatment of a variety of diseases. The different extract of roots of $A$. Indica were evaluated for their anti-inflammatory, antipyruitic and mast cell stabilizing activity. The aqueous extract of the roots of $A$. Indica is used as decoction for the ailment of number of diseases including snake bite treatment. A. Indica was traditionally uses as antidotes for snake bite. A. Indica has long been used in Indian subcontinents in the traditional system of medicine to treat chlorea, fever, bowel troubles, ulcers, leprosy, skin diseases, menstrual problems. Species of Aristolochia are associated with aristolochic acid nephropathy (AAN), a renal interstitial fibrosis and upper urinary tract cancer (UUC). The essential oil of aristolochia indica such as betacaryophyllene and alpha humulene shows an antibacterial activity. (C) 2019 iGlobal Research and Publishing Foundation. All rights reserved.

Cite this article as: Marwaha, M.; Kumar, D.; Sharma, P. Aristolochia indica: A Review. Indo Global J. Pharm. Sci., 2019; 9(2Suppl.): 158. DOI: http://doi.org/10.35652/IGJPS.2019.92S56.

Indo Global Journal of Pharmaceutical Sciences( ISSN 2249 1023; CODEN- IGJPAI; NLM ID: 101610675) indexed and abstracted in CrossRef (DOI Enabling), UGC CARE Journal List, EMBASE(Elsevier), National Library of Medicine (NLM) Catalog, ResearchGate, Publons, CAS (ACS), Index Copernicus, Google Scholar and many more. For further details, visit http://iglobaljournal.com

This is a special issue as an outcome of 'RAPSCON-2019' sponsored by APTI and organized by Sri Sai College of Pharmacy, Manawala, Amritsar, Punjab, India. Relaxation offered in journal format. 